2013

\title{
Ethical Lawyering in a Global Community
}

Trevor C. W. Farrow

Osgoode Hall Law School of York University, tfarrow@osgoode.yorku.ca

Follow this and additional works at: https://digitalcommons.osgoode.yorku.ca/clpe

Part of the Legal Ethics and Professional Responsibility Commons

\section{Recommended Citation}

Farrow, Trevor C. W., "Ethical Lawyering in a Global Community" (2013). Comparative Research in Law \& Political Economy. Research Paper No. 9/2013.

https://digitalcommons.osgoode.yorku.ca/clpe/258

This Article is brought to you for free and open access by the Research Papers, Working Papers, Conference Papers at Osgoode Digital Commons. It has been accepted for inclusion in Comparative Research in Law \& Political Economy by an authorized administrator of Osgoode Digital Commons. 


\section{OSGOODE}

\section{OSGOODE HALL LAW SCHOOL}

Comparative Research in Law \& Political Economy

RESEARCH PAPER SERIES

Research Paper No. 9/2013

\section{Ethical Lawyering in a Global Community}

Trevor C. W. Farrow

\section{Editors:}

Peer Zumbansen (Osgoode Hall Law School, Toronto, Director Comparative Research in Law and Political Economy)

John W. Cioffi (University of California at Riverside)

Leeanne Footman (Osgoode Hall Law School, Toronto, Production Editor)

Comparative Research in Law \& Political Economy 
IsAAC PitBlado LeCTURES 2012

"LEGAL BOUNDARIES IN A GLOBAL WORLD"

Ethical LaWyering in a Global Community

Trevor C. W. FARrow*

WINNIPEG, MANITOBA

1 DECEMBER 2012

\begin{abstract}
The pressures and opportunities of globalization have dramatically changed the nature of legal practice. How and why we practice law? For whom and whose benefit? In what contexts? And on what terms? The answers to these questions are continuously changing as a result of current global trends. The communities served by lawyers, the practice contexts in which they work and the issues that they face are increasingly diverse, complex, transnational and global in character. All of these challenges demand new competencies and raise a host of new issues about ethics and professionalism. As a threshold matter, more and more lawyers engage in transnational practices, including, for example, corporate, family, labour and human rights practices. Knowledge of international and comparative legal systems and the norms of professional conduct in other jurisdictions is increasingly essential in such settings. However, beyond these self-consciously transnational contexts, it is perhaps even more important to acknowledge that few if any areas of practice remain in which legal professionals can rely solely on the knowledge of a single, domestic legal system. Local communities are microcosms of global diversity in which a multiplicity of official and unofficial legal orders and ethical systems overlap. The increasingly pluralistic nature of modern local communities demands that the vast majority of lawyers will be required to work in contexts that require cross-cultural competencies and sensitivities to diverse legal and moral perspectives. Put simply, the complexity of today's world is not just an issue for international lawyers - it is an issue for all lawyers. As such, thinking about lawyering in a global community and how we not only practice it, but also how we learn about and regulate it, has become of central concern for practitioners, educators and regulators. That central concern is the subject of this lecture, which asks the following question: why should lawyers care about being more open to the global? In developing a response to this question, this lecture looks at three issues: pluralism, professionalism and pragmatism, all of which, together, provide a basis for an answer to this inquiry.
\end{abstract}

\footnotetext{
${ }^{*}$ Trevor C. W. Farrow, AB (Princeton), BA/MA (Oxford), LLB (Dalhousie), LLM (Harvard), PhD (Alberta), is an Associate Professor at Osgoode Hall Law School in Toronto (tfarrow@osgoode.yorku.ca). He is also the Chair of the Canadian Forum on Civil Justice and the Acting Director of the York Centre for Public Policy and Law. His research and teaching focus on the administration of civil justice, including legal process, legal and judicial ethics and education, dispute resolution and advocacy. He is a member of the Law Society of Upper Canada, (LSUC) and formerly a litigation lawyer at the Torys law firm in Toronto. He is the author of numerous articles, reports and books, including a forthcoming monograph entitled: Civil Justice, Privatization and Democracy (Toronto: University of Toronto Press, in progress).
} 


\section{INTRODUCTION}

[T] he make-up of our country is changing.... And that creates new responsibilities for ... the legal profession.... I think it's always a good idea for people who serve an ideal-such as the public good... - to understand who is the Canadian public of today, who are the people needing your services, and why knowing this is in the public interest. ${ }^{1}$

We live in rapidly changing times.... We all recognize the changes taking place. But we must go beyond this understanding. We must also be willing to embrace and adapt to change. We must scrutinize our social contract - both with the public and internally - to ensure that we stay relevant ... and continuously strive for the good. ${ }^{2}$

Given the illustrious career of Isaac Pitblado and the more than 50 year history of this lecture series, it is truly an honour to be invited to give one of this year's keynote lectures. I am grateful to the Law Society of Manitoba, the University of Manitoba, Faculty of Law, the Manitoba Bar Association, the Isaac Pitblado Lectures Selection Committee and Jennifer Schulz for the generous invitation to give this lecture as part of this year's Isaac Pitblado Lectures. Hilary Fender provided excellent research assistance and Tracy Lloyd provided very helpful administrative assistance.

My approach to this lecture has been significantly influenced by our mandatory first year Osgoode Hall Law School course entitled: "Ethical Lawyering in a Global Community". We started that course six years ago as part of a major reform to our first year curriculum. ${ }^{3}$ And although I was the inaugural director, and continue to be the director, for that course, many people - including former co-instructors, graduate teaching assistants, students and others - have

\footnotetext{
${ }^{1}$ Rt. Hon. Adrienne Clarkson, "Speech on the Occasion of an Honorary Doctorate of Laws Degree from the Law Society of Upper Canada" (27 February 2003), online: $<$ http://archive.gg.ca/media/doc.asp?lang=e\&DocID=1091>.

${ }^{2}$ Rt. Hon. David Johnston, Governor General of Canada, "Canadian Bar Association's Canadian Legal Conference - The Legal Profession in a Smart and Caring Nation: A Vision for 2017" (Halifax, August 14, 2011), online: $<$ http://www.gg.ca/document.aspx?id=14195>.

${ }^{3}$ See Osgoode Hall Law School, Office of the Dean, Annual Report-Academic Year 2006-2007, online: Osgoode Hall Law School < http://www.osgoode.yorku.ca/sites/default/files/documents/about/annualreport_2006-2007.pdf> at pp. 2,7 .
} 
influenced not only the course outline and materials, but also my thinking about the issues that we cover. ${ }^{4}$

Isaac Pitblado, K.C. (1867-1964), for whom this lecture series is named, can be seen as the embodiment of at least some of the inter-jurisdictional aspects of what I am going to talk about today. The Manitoba Pitblado family formed one branch of a large North American family with Scottish roots. Isaac Pitblado's father, Charles Bruce Pitblado (1836-1913), came from Fife and settled in Nova Scotia where he became a Presbyterian minister. It was in Nova Scotia where Isaac Pitblado was born. ${ }^{5}$ His year of birth was 1867 , the year in which colonialists and immigrants came together, with backgrounds from several parts of the world, to create the newly formed Dominion of Canada. Isaac Pitblado then moved west where he studied and practiced law and held many honoured positions including the $7^{\text {th }}$ presidency of the Canadian Bar Association (CBA). ${ }^{6}$ His work, involving numerous issues and concerns including transportation and telecommunication, was inter-jurisdictional in nature. And his personal life was equally inter-jurisdictionally influenced, including his second marriage (in 1907) to May Edith Lunn Lazier of Minneapolis, Minnesota, with whom he had two daughters and one son. ${ }^{7}$ With Scottish roots, an East Coast Confederation birth, a religious upbringing, a cross-country

\footnotetext{
${ }^{4}$ I am particularly grateful for, and acknowledge, the work and ideas of Janet Mosher (who also provided very helpful comments on an early draft of this lecture), Patrick Monahan, Allan Hutchinson, Craig Scott, Robert Wai, Faisal Bhabha, Janet Walker, Fay Faraday, Adam Dodek, Chantal Morton, Rusby Chaparro, Graham Hudson, Stuart O'Connell, Mary Stokes, Fenner Stewart, Maria Panezi, Sujith Xavier, Graham Hudson, Claire Mumme, Patricia Hania, Jennifer Leitch and David Hughes, all of whom have significantly influenced my thinking on the topic, which has been further developed for this lecture.

${ }^{5}$ For the purpose of this biographical introduction, I have reviewed several sources of information including the Manitoba Historical Society, Memorable Manitobans: Isaac Pitblado (1867-1964), online:

$<$ http://www.mhs.mb.ca/docs/people/pitblado_i.shtml>; and University of Manitoba Libraries, Archives \& Special Collections, Pitblado Family fonds (1836-1977), "Biographical Sketch", online:

$<$ http://umanitoba.ca/libraries/units/archives/collections/complete_holdings/rad/mss/pitblado_family.shtml $>$.

${ }^{6}$ CBA, "Past CBA Presidents", online: CBA <http://www.cba.org/cba/info/main/PrintHtml.aspx?DocId=13167>.

${ }^{7}$ The Manitoba Historical Society, Memorable Manitobans: Isaac Pitblado (1867-1964), supra note 5.
} 
relocation, a vibrant professional career with national interests and an international family, Pitblado's life can be seen as influencing and being influenced by a variety of backgrounds, cultures, contexts, customs and laws. It is these elements of pluralism of Isaac Pitblado's life that I want to start from for the purpose of this lecture.

Today, the pressures and opportunities of globalization, often delivered through relentless developments in technology and transportation, have dramatically changed the nature of legal practice. How and why we practice law? For whom and whose benefit? In what contexts? And on what terms? The answers to these questions are continuously changing as a result of current global trends. The communities served by lawyers, the practice contexts in which they work and the issues that they face are increasingly diverse, complex, transnational and global in character. All of these challenges demand new competencies and raise a host of new issues about ethics and professionalism. As a threshold matter, more and more lawyers engage in transnational practices, including, for example, corporate, family, labour and human rights practices. Knowledge of international and comparative legal systems and the norms of professional conduct in other jurisdictions is increasingly essential in such settings. However, beyond these self-consciously transnational contexts, it is perhaps even more important to acknowledge that few if any areas of practice remain in which legal professionals can rely solely on the knowledge of a single, domestic legal system. Local communities are microcosms of global diversity in which a multiplicity of official and unofficial legal orders and ethical systems overlap. The increasingly pluralistic nature of modern local communities demands that the vast majority of lawyers will be required to work in contexts that require cross-cultural competencies and sensitivities to diverse legal and moral perspectives. Put simply, the complexity of today's world is not just an issue for international lawyers - it is an issue for all lawyers. 
As such, thinking about lawyering - good, ethical, lawyering - in a global community and how we not only practice it, but also how we learn about and regulate it, has become of central concern for practitioners, educators and regulators. That central concern is the subject of this lecture. I am going to approach the topic by asking the following question: why should Canadian lawyers care about being more open to the global? In developing a response to this question, I am going to look at three issues: pluralism, professionalism and pragmatism, all of which, together, provide a basis for an answer to this inquiry.

\section{$\underline{\text { 1. Pluralism }}$}

Before I talk about pluralism, I first need to say a word or two about globalization. Not long ago, the nature and extent of modern globalization was still very much a topic of political, economic and social debate. ${ }^{8}$ In the early days of the World Trade Organization, for example, the streets of Seattle were shut down in a very aggressive and effective way mostly by thousands of people who came together to discuss and protest the social and political implications of the

\footnotetext{
${ }^{8}$ See e.g. David Held et al., Global Transformations: Politics, Economics and Culture (Stanford: Stanford University Press, 1999); William Twining, Globalisation and Legal Theory (London: Butterworths, 2000); Paul Hirst and Grahame Thompson, Globalization in Question: The International Economy and the Possibilities of Governance, 2d ed. (Cambridge: Polity Press, 1999); Dani Rodrik, Has Globalization Gone Too Far? (Washington, D.C.: Institute of International Economics, 1997); Joseph E. Stiglitz, Globalization and its Discontents (New York: W.W. Norton, 2002); A.S. Bhalla, ed., Globalization, Growth and Marginalization (Ottawa: International Development Research Centre, 1998); Barry B. Hughes, International Futures: Choices in the Creation of a New World Order, 2d ed. (Boulder, CO: Westview Press, 1996); David Held and Anthony McGrew, "The Great Globalization Debate: An Introduction" in The Global Transformations Reader: An Introduction to the Globalization Debate, 2d ed. (Polity Press, 2003) 1. For further sources on the topic of globalization and related governance issues, see e.g. Boaventura de Sousa Santos, "Nature and Types of Globalization(s)" in Toward A New Legal Common Sense: Law, Globalization, And Emancipation, 2d ed. (Butterworths, 2002) 177; Janine Brodie, "Introduction: Globalization and Citizenship Beyond the National State" (December 2004) 8:4 Citizenship Studies 323; Janine Brodie and Linda Trimble, "Reinventing Canada, An Overview" in Janine Brodie and Linda Trimble, eds., Reinventing Canada: Politics of the $21^{\text {st }}$ Century (Toronto: Prentice Hall, 2003) 1; Elizabeth Smythe, "Canadian Sovereignty and Global Trade and Investment Rules" in Brodie and Trimble, eds., Reinventing Canada: Politics of the $21^{\text {st }}$ Century, supra at c. 21; David Schneiderman, Constitutionalizing Economic Globalization: Investment Rules and Democracy's Promise (Cambridge, New York: Cambridge University Press, 2008); Erin A. O'Hara and Larry E. Ribstein, The Law Market (Oxford, New York: Oxford University Press, 2009); John H. Dunning, ed., Making Globalization Good: The Moral Challenges of Global Capitalism (Oxford, New York: Oxford University Press, 2003); Alfred C. Aman, The Democracy Deficit: Taming Globalization Through Law Reform (New York: New York University Press, 2004).
} 
seemingly unlimited and often undemocratically regulated free flow of goods, services and capital throughout the world. ${ }^{9}$ Many concerns were voiced. However, notwithstanding these concerns, there were also at least several aspects of agreement between those who supported globalization and those who did not: globalization is big, it is powerful, and it increasingly involves many if not most aspects of the world's economies and cultures. ${ }^{10}$ Clearly the WTO did not start the modern globalization discussion, nor did the debate about globalization start or end with the "Battle in Seattle". ${ }^{11}$ However, more than ten years on, we are still seeing the engine of globalization continuing to gain speed at a seemingly unyielding pace as we become more and more interconnected as a global community.

So what is globalization? As I have stated elsewhere:

More than simply an historically-contingent event, globalization is a nuanced and expansive process involving a wide range of geographically-relevant political, economic, social and cultural connections and changes that are being created by and visited upon our personal and community affairs. It therefore involves - in this broad sense - much more than what is often seen largely as a process of increased and interconnected trade, technology, and the movement of capital. ${ }^{12}$

\footnotetext{
${ }^{9}$ See Trevor C.W. Farrow, "Negotiation, Mediation, Globalization Protests \& Police: Right Processes; Wrong System, Parties, Issues \& Time” (2003) 28 Queen's L.J. 665 at 667. See also generally Trevor C.W. Farrow, "Citizen Participation and Peaceful Protest: Let's Not Forget APEC" in Patricia Hughes and Patrick A. Molinari, eds., Participatory Justice in a Global Economy: The New Rule of Law (Montréal: Les Éditions Thémis, 2004$) 205$.
}

${ }^{10}$ For a useful discussion of historical waves of globalization and the nature and character of the current wave, see Thomas L. Friedman, The Lexus and the Olive Tree: Understanding Globalization (New York: Random House, 1999).

${ }^{11}$ Prior to the Seattle protests, the presence of NGOs and anti-globalization protesters in Rio de Janeiro, Brazil at the UN Conference on Environment and Development in 1992 (the "Earth Summit") was an important moment for active and widespread debate within civil society about the nature and extent of sustainable globalization. For background information, see e.g. United Nations, Department of Public Information, "UN Conference on Environment and Development (1992)" (United Nations, 23 May 1997), online: United Nations $<\mathrm{http}$ //www.un.org/geninfo/bp/enviro.html $>$.

12 Trevor C.W. Farrow, “Globalization, International Human Rights, and Civil Procedure” (2003) 41 Alta. L. Rev. 671 at 675. For a recent discussion of the topic, see Trevor C.W. Farrow, Civil Justice, Privatization and Democracy (Toronto: University of Toronto Press, in progress) c. 6. See earlier Farrow, "Negotiation, Mediation, Globalization Protests \& Police: Right Processes; Wrong System, Parties, Issues \& Time", supra note 9; Trevor C.W. Farrow, "Globalizing Approaches to Legal Education and Training: Canada to Japan" (2005) 38 Hosei Riron J. L. \& Pol. 144; Trevor C.W. Farrow, "Reviewing Globalization: Three Competing Stories, Two Emerging Themes, and How Law Schools Can and Must Participate" (2003) 13 Meikei L. Rev. 176, trans. (into Japanese) by 
For the purpose of this lecture, the important elements of what I think of as globalization are simply, and descriptively, its breadth and depth. Globalization, broadly defined, very much involves a wide range of world forces - culture, religion, finance, sociology, information, technology, etc. - that impact and often define our local daily lives. And the depth of this impact is massive. There are few corners of the globe in which one cannot find the meaningful touch of globalization.

In Canada, for example, 2011 demographic figures show that more than 200 languages were reported as a home language or mother tongue. ${ }^{13}$ Further, one-fifth of the country's population - more than 6 million people - spoke a language other than French or English at home. ${ }^{14}$ In 2006, approximately $20 \%$ of the Canadian population was foreign-born (again more than 6 million people), and that percentage is projected to rise to between $25 \%$ and $28 \%$ by 2031. ${ }^{15}$ The diversity of our immigrant population has increased over the past 30 years as well, with the Asian-born portion of those who are foreign-born increasing and, in 2006, exceeding

M. Kuwahara, (2003) 44 Aichigakuin L. Rev. 29, rep'd (2004) 5 J. Centre Int'l Stud. 1; Trevor C.W. Farrow, "Regional Integration and Dispute Resolution in the Free Trade Area of the Americas" in Andy Knight et al. eds., Re-Mapping the Americas: Globalization, Regionalization and the FTAA (Edmonton: University of Alberta Press, forthcoming); Trevor C.W. Farrow, "Dispute Resolution, Access to Civil Justice and Legal Education" (2005) 42 Alta. L. Rev. 741 at 742, n. 5 and 787, n. 292 and accompanying text; Trevor C.W. Farrow and Sheilah L. Martin, "Globalization \& the Law: An Introduction" (2003) 41 Alta. L. Rev. 657; Trevor C.W. Farrow, Embracing the Complex Personality of International Law: Formalism, Anti-Formalism and the Globalization Construct (LL.M. Thesis, Harvard Law School, 2000) [unpublished, archived at Harvard University Library].

${ }^{13}$ Statistics Canada, The Daily, 2011 Census of Population: Linguistic Characteristics of Canadians (Ottawa: Statistics Canada, 24 October 2012), online: Government of Canada <http://www.statcan.gc.ca/dailyquotidien/121024/dq121024a-eng.htm>.

${ }^{14} \mathrm{Ibid}$. This number included people speaking a language other than French or English alone, or in combination with French or English.

${ }^{15}$ Statistics Canada, Demography Division, Projections of the Diversity of the Canadian Population, 2006 to 2031 (Ottawa: Minister of Industry, March 2010) at 15-17, online: Government of Canada $<$ http://www.statcan.gc.ca/pub/91-551-x/91-551-x2010001-eng.pdf $>$. 
those who are European-born. ${ }^{16}$ According to these trends, it is projected that $55 \%$ of Canada's foreign-born population will come from Asia by 2031. In terms of Manitoba, immigration has had a significant influence on this province's recent population growth, with twice as many immigrants (over 64,000) arriving since 2006 as compared to the period between 2001 and 2006 (during which slightly less than 34,000 immigrants arrived). ${ }^{17}$

Economic indicators of globalization are consistent with these striking cultural statistics. For example, in 2011, the value of global merchandise exports grew by $20 \%$ while, at the same time, the value of commercial services grew by $11 \%{ }^{18}$ As far as Canada is concerned, this country exported, for example, over $\$ 60$ billion in agricultural products in 2011 (up approximately $18 \%$ from the previous year) while at the same time we imported over $\$ 68$ billion in fuels and mining products (up approximately $35 \%$ from the previous year). ${ }^{19}$ While we still can - and should - debate the merits of this growth and the ways in which it can be managed, sustained, promoted or curtailed, there is no doubt - on any calculus (as hinted at by the title of this year's lecture series) - that we live in a fully globalized world.

So what? Why do we care about globalization? For the purpose of this lecture, we care about globalization because of what I see as its direct impact on who we are and how we relate to one another, not just as states and institutions at the international level, but equally if not more importantly as individuals in our homes, schools and local places of work and leisure. Our

\footnotetext{
${ }^{16} \mathrm{Ibid}$. at 17.

${ }^{17}$ Statistics Canada, Demography Division, The Canadian Population in 2011: Population Counts and Growth (Ottawa: Statistics Canada, 30 May 2012) at pt. 2, online: Government of Canada $<\mathrm{http} / / /$ www12.statcan.gc.ca/census-recensement/2011/as-sa/98-310-x/98-310-x2011001-eng.cfm\#a3>.

${ }^{18}$ World Trade Organization, International Trade Statistics 2012 (Geneva: World Trade Organization, 2012) at 11, online: WTO $<$ http://www.wto.org/english/res_e/statis_e/its2012_e/its2012_e.pdf $>$.

${ }^{19} \mathrm{Ibid}$. at 54-55.
} 
communities have become microcosms of different languages, cultures, business practices and religions. As such, who we are and what we do is dramatically diverse. And because of this, the norms and expectations that guide our behaviour - including religion, custom, habits, rules and laws - have become increasingly complex. In his chapter called the "universality of the human problems", Philip Jessup commented that as a result of the increasing complexity of the human condition, the rules that govern our basic relationships have become equally complex, interconnected and inter-jurisdictional in character. According to Jessup:

As man has developed his needs and his facilities for meeting his needs, the rules become more numerous and more complicated. History, geography, preferences, convenience, and necessity have dictated dispersion of the authority to make the rules men live by. Some rules are made by the head of the family, whether it be father or mother, such as "Wash your hands before supper." Some rules made by ecclesiastical authorities as in specifying times and manners of fasting. Some are made by corporations regulating their sales agencies.... Other rules are made by secret societies, by towns, cities, states. Still others are made by international organizations such as the ... International Monetary Fund.... ${ }^{20}$

All of this diverse body of regulation can be fairly described as "law". As Jessup acknowledged, '[n]owadays it is neither novel nor heretical to call all of these rules 'law'.,"21 Because if the point of understanding law, particularly from a client perspective, is to understand how to manage individual and collective rights and relationships, then it is important to include in this picture the broad range of norms and rules that actually frame all aspects of today's legal landscape. However, even if one does not agree that all of these norms and rules can or should be called "law", it must now be seen as common ground that, put simply, there is a pluralism of norms that guide our daily conduct, relationships and affairs. This is not a new observation. Moral and political philosophers - from before Socrates, through the Enlightenment and up to

\footnotetext{
${ }^{20}$ Philip C. Jessup, Transnational Law (New Haven: Yale University Press, 1956) at 8-9.

${ }^{21}$ Ibid. at 9.
} 
today - have been thinking about the best way to understand and regulate individual and collective action for millennia. So too sociologists, who for a long time have been studying various formal, informal and hybrid approaches to communal regulation. ${ }^{22}$ But as far as the legal profession goes - not so much. Provincially educated and regulated lawyers have been comparatively slow to understand their role as much more than a very domestic and local calling, which is guided by a relatively narrow set of formal legal instruments. Of course the relatively few lawyers who practice before the International Court of Justice or the Dispute Settlement Body of the World Trade Organization require an active understanding of world practices and global legal instruments. And admittedly these are not the only lawyers who have been concerned with both local and foreign business, cultural and legal practices. However, as a general matter, beyond those very self-consciously international legal moments, few lawyers have truly seen themselves as global actors guided by a diverse set of norms. And this, in my view, is a significant blind-spot in our individual and collective professional self-awareness.

Pluralism has become a defining force in terms of how essentially all lawyers can and should understand their professional roles. ${ }^{23}$ For my purpose here, there are two key elements of pluralism. First, largely (although not exclusively) as a result of globalization, clients have become increasingly diverse. ${ }^{24}$ This aspect of pluralism very much tracks the increasing

\footnotetext{
${ }^{22}$ See e.g. Leopold Pospisil, "Legal Levels and Multiplicity of Legal Systems" in Anthropology of Law: A Comparative Perspective (New York: Harper \& Row, 1971) 97; Sally Engle Merry, "Legal Pluralism" (1988) 22 Law \& Soc’y Rev. 869; Franz von Benda-Beckmann, “Comment on Merry” (1988) 22 Law \& Soc’y Rev. 897.

${ }^{23}$ For useful and relatively recent discussions on this topic, see Carrie Menkel-Meadow, "Why and How to Study "Transnational Law" (2011) 1:1 UC Irvine Law Rev. 97; William Twining, "Normative and Legal Pluralism: A Global Perspective" (2010) 20 Duke J. Comp. \& Int'l L. 473. See also Paul Schiff Berman, "Global Legal Pluralism" (2007) 80 S. Cal. Rev. 1155; Frédéric Mégret, "Globalization and International Law" (4 August 2008) in Max Planck Encyclopedia of International Law (Oxford: Oxford University Press, 2009); Ian Holloway, Q.C., "The Canadian Lawyer in the Twenty-First Century" (September 2011) 69:5 The Advocate 691 at 693.

${ }^{24}$ See supra notes 13-17 and accompanying text. It is important to acknowledge that the diversity of Canada's population owes much not only to its immigrant roots, but also to its aboriginal roots as well.
} 
diversity of Canada's population. ${ }^{25}$ Second, an increasing societal diversity brings with it an increasing pluralism of the norms, rules, practices and expectations that guide the relationships and affairs of that diverse population. For lawyers, this means that the diversity of clients and client activities, as well as the pluralism of the norms and rules that guide and regulate those activities, amount to a broad notion of pluralism that lawyers must now understand and actively embrace in all areas of practice in order properly, and competently, to service their clients. Doing otherwise will ignore the full range of interests and needs of many - if not most - clients.

We can see the relevance of pluralism at the intersection of essentially all aspects of social life and legal practice. For example, it is becoming increasingly likely that a family law client in Toronto will want her divorce lawyer to have some sense of the impact of Islam, through the operation of Sharia law, on a couple's division of assets. ${ }^{26}$ And if the same client wants to set up an investment vehicle, she may also need her lawyer to be conversant with Sharia practices as they apply to commercial relationships. At the same time, it will be important for a corporate lawyer in Winnipeg who is being asked to oversee a resource transaction involving crown, private and native lands - given obligations created by the duty to consult ${ }^{27}$ - to have a sense not only of all applicable federal and provincial laws, but also of the many native and non-native traditions, norms, cultures and practices that may come into play. ${ }^{28}$ Similarly, if a board of directors were to seek advice from legal counsel on a forward looking approach to appointing

\footnotetext{
${ }^{25}$ Ibid.

${ }^{26}$ For an earlier discussion, see e.g. Trevor C.W. Farrow, "Re-Framing the Sharia Arbitration Debate" (2006) 15:2 Constitutional Forum 79.

${ }^{27}$ See e.g. Beckman v. Little Salmon/Carmacks First Nation, [2010] 3 S.C.R. 103.

${ }^{28}$ See e.g. Delgamuukw v. British Columbia, [1997] 3 S.C.R. 1010; R. v. Van der Peet, [1996] 2 S.C.R. 507. See further Rupert Ross, "Exploring Criminal Justice and the Aboriginal Healing Program", Discussion Paper presented at Chief Justice of Ontario's Advisory Committee on Professionalism, Third Colloquium on the Legal Profession (2004), online: $<$ http://www.lsuc.on.ca/media/third_colloquium_rupert_ross.pdf $>$.
} 
board members and in particular women and members of minority groups, or if the board were looking for advice on retaining outside counsel, in addition to human rights and other legislation, the directors would want to be advised of current diversity-related expectations, trends and initiatives ${ }^{29}$ - found in various forms of soft law ${ }^{30}$ and other practices - that might influence their decision. If a real estate lawyer, negotiating on behalf of her client, is successfully to broker a deal between disputing parties of different cultural backgrounds, there is no doubt that she needs to be equally conversant with cultural influences on the dispute resolution process as with basic negotiation practices. ${ }^{31}$ Clinic and poverty lawyers are increasingly being asked to understand not only the legal landscape of various issues, but equally the social, economic and cultural contexts of many issues, clients and communities. And if a criminal lawyer, a Crown attorney, or an immigration officer is properly to represent, prosecute or administer the file of individuals of different genders, races, ages and heritages, they need to understand the differential impacts that race, gender, heritage, age and culture can potentially have on men, women and children in various contexts in which legal rights are being determined. ${ }^{32}$

\footnotetext{
${ }^{29}$ See e.g. A Call to Action Canada, "Mission Statement", online: <http://acalltoactioncanada.com/missionstatement>.

${ }^{30}$ In addition to A Call to Action Canada's initiative (see ibid.), other examples of "soft law" include initiatives from the International Organization for Standardization (online: ISO <http://www.iso.org/iso/home.html $>$ ) and the UN Global Compact (online: UN <http://www.unglobalcompact.org/AboutTheGC/TheTenPrinciples/index.html $>$ ). For a collection of discussions of soft law and its growing importance in the global economy, see John J. Kirton and Michael J. Trebilcock, eds., Hard Choices, Soft Law: Voluntary Standards in Global Trade, Environment and Social Governance (Aldershot: Ashgate Publishing, 2004). In the administrative context, see e.g. Thamotharem v. Canada (Minister of Citizenship and Immigration), [2008] 1 F.C.R. 385 at paras. 60-64 (F.C.A.), leave to appeal to S.C.C. refused, [2007] S.C.C.A. No. 394. See further Laura Pottie \& Lorne Sossin, "Demystifying the Boundaries of Public Law: Policy, Discretion, and Social Welfare" (2005) 38 U.B.C. L. Rev. 147.

${ }^{31}$ See e.g. Michelle LeBaron, "Shapeshifters and Synergy: Toward a Culturally Fluent Approach to Representative Negotiation" in Colleen M. Hanycz, Trevor C.W. Farrow and Frederick H. Zemans, The Theory and Practice of Representative Negotiation (Toronto: Emond Montgomery, 2008) c. 6.

${ }^{32}$ See e.g. R. v. Lavalee, [1990] 1 S.C.R. 852; R. v. S. (R.D.), [1997] 3 S.C.R. 484; Baker v. Canada (Minister of Citizenship and Immigration), [1999] 2 S.C.R. 817; R. v. Gladue, [1999] 1 S.C.R. 688.
} 
The simple but important point here is this: the world has changed. Client needs and interests have therefore changed. And lawyers need to keep up and adapt in order properly to serve their clients. Much of the driver of this change comes in the form of a pluralism of voices and norms that drive and guide legal practice as a result of the intense forces of globalization that have embraced essentially all aspects of our individual and collective activities and relationships. So for no other reason, as a descriptive matter, the world in which lawyers live and work is demanding a much stronger and more nuanced understanding of pluralism.

\section{Professionalism}

A second aspect of this inquiry of why Canadian lawyers should be more open to the global involves professionalism. Put simply, various aspects of professional responsibility demand an increased attentiveness to globalism and pluralism. As a starting point, we can look to various examples of provincial legislative documents that set up the self-regulating legal professional bodies in Canada. In this province, Manitoba, the Legal Profession Act provides that the "purpose" of the Law Society of Manitoba (LSM) is "to uphold and protect the public interest in the delivery of legal services...."33 In Ontario, the Law Society of Upper Canada (LSUC) has gone further with its foundational promise to society. In the Law Society Act, lawyers - through their governing body - take on duties to: "maintain and advance the cause of justice and the rule of law"; "act so as to facilitate access to justice"; and "protect the public interest." ${ }^{34}$ If we ask the questions "what public?" and "whose interest?", and if we really care about the answers, then we will quickly get back to our earlier discussion about the diversity of the communities that are served by lawyers - both locally and globally. Saying that lawyers act

\footnotetext{
${ }^{33}$ Legal Profession Act, C.C.S.M. c. L.107 (assented to 9 August 2002) at s. 3(1).

${ }^{34}$ Law Society Act, R.S.O. 1990, c. L.8 at s. 4.2.
} 
"in the public interest" necessarily requires lawyers to recognize and embrace the fact that the "public interest" represents the collective well-being of an increasingly diverse society. And the same attentiveness should be required in terms of promises regarding "the rule of law", "justice" and "access to justice". ${ }^{35}$ What is meant by those terms is left open by the legislative instruments. ${ }^{36}$ But to the extent that justice means something different than the rule of law (which is the only reasonable assumption given the inclusion of both terms, for example, in Ontario's legislative framework), then what justice entails, for whom it must be made accessible, and how, are all considerations that need to take seriously the demographic makeup of the communities on behalf of which these promises were made. Otherwise, the promises are essentially meaningless.

Further, most rules committees have sought to incorporate these various legislative promises, with varying degrees of specificity and inclusion, into their rules of professional regulation. For example, again looking to this province, Manitoba's Code of Professional Conduct states that its "primary concern" is the "protection of the public interest" in a "complex

\footnotetext{
${ }^{35}$ See ibid.

${ }^{36}$ For discussions on the rule of law and access to justice, see e.g. Farrow, Civil Justice, Privatization and Democracy, supra note 12 at cc. 2 and 7. For further treatments of access to justice, see e.g. Trevor C.W. Farrow, "Sustainable Professionalism" (2008) 46 Osgoode Hall L.J. 51 at 96; Farrow, "Dispute Resolution, Access to Civil Justice and Legal Education", supra note 12 at 798; LSUC, "Accessing the justice system: Exploring perceptions" (Focus article on access to justice) Gazette 16:1 (Winter 2012) 5; George C. Pavlich, Justice Fragmented: Mediating community disputes under postmodern conditions (London, New York: Routledge, 1996) c. 2; Roderick A. MacDonald, "Access to Justice and Law Reform" (1990) 10 Windsor Y.B. Access Just. 287; Roderick A. Macdonald, "Whose Access? Which Justice?" (1992) 7 Can. J.L. \& Soc. 175; Roderick A. Macdonald, "Access to Justice in Canada Today: Scope, Scale and Ambitions" in Julia Bass, W.A. Bogart and Frederick H. Zemans, eds., Access to Justice for a New Century - The Way Forward (Toronto: LSUC, 2005) at 19-31, 99-101; Marc Galanter, "Access to Justice as a Moving Frontier" in Access to Justice for a New Century, ibid. at 147-152; Michael Trebilcock, "Report of the Legal Aid Review 2008" (2008), online: Legal Aid Ontario $<$ http://www.legalaid.on.ca/en/publications/downloads/advisorygroups/transform-poverty_trebilcock.pdf $>$; Ab Currie, "A National Survey of the Civil Justice Problems of Low- and Moderate-Income Canadians: Incidence and Patterns" (2006) 13 Int'1 J. Legal Prof. 217; Lorne Sossin, “The Public Interest, Professionalism, and Pro Bono Publico" (2008) 46 Osgoode Hall L.J. 131 at 134, n. 5 and accompanying text. See also Patricia Hughes and Janet E. Mosher, guest eds., "Access to Justice”, Special Issue (2008) 46:4 Osgoode Hall L. J.; Michael Trebilcock, Anthony Duggan and Lorne Sossin, eds., Middle Income Access to Justice (Toronto: University of Toronto Press, 2012).
} 
and ever-changing society". ${ }^{37}$ Ontario has similar provisions in its governing rules, ${ }^{38}$ as do both the national model rules of the $\mathrm{CBA}^{39}$ and the Federation of Law Societies of Canada (FLSC). ${ }^{40}$ Perhaps the most interesting of these general statements for the purpose of this lecture is found in the Preface to the FLSC's Model Code. It specifically acknowledges, as set out below, the impact on the legal profession of advances in technology and changes in the cultural diversity of Canada:

The practice of law continues to evolve. Advances in technology, changes in the culture of those accessing legal services and the economics associated with practising law will continue to present challenges to lawyers. The ethical guidance provided to lawyers by their regulators should be responsive to this evolution. Rules of conduct should assist, not hinder, lawyers in providing legal services to the public in a way that ensures the public interest is protected. ${ }^{41}$

Clearly, as the Model Code indicates - which is also consistent with the statements set out at the beginning of this lecture from former Governor General Adrienne Clarkson ${ }^{42}$ and current Governor General David Johnston ${ }^{43}$ - ethical guidance for lawyers in Canada must not only acknowledge, but must respond to and reflect the changing cultural landscape in which lawyers practice in order for the legal profession to stay "relevant". ${ }^{44}$

\footnotetext{
${ }^{37}$ LSM, Code of Professional Conduct (adopted 17 June 2010, effective 1 January 2011) at "Preface". See further c. 1.

${ }^{38}$ See e.g. LSUC, Rules of Professional Conduct (effective 1 November 2000) at r. 1.03. See further ibid. at rr. 2.01(1) and 2.02(5.2) (Commentaries).

${ }^{39}$ See e.g. CBA, Code of Professional Conduct (rev. ed. 2009) at "President's Message", "Preface" (on which Manitoba's "Preface" is modelled) and c. I.

${ }^{40}$ See e.g. FLSC, Model Code of Professional Conduct (as amended 13 December 2011) at "Preface" and c. 1.

${ }^{41}$ Ibid. at "Preface".

${ }^{42}$ See supra note 1.

${ }^{43}$ See supra note 2.

${ }^{44}$ Ibid.
} 
In addition to these general statements, some provincial codes have gone further in terms of specifically acknowledging the importance of diversity. For example the LSUC's Rules of Professional Conduct provide that:

...a lawyer has special responsibilities by virtue of the privileges afforded the legal profession and the important role it plays in a free and democratic society and in the administration of justice, including a special responsibility to recognize the diversity of the Ontario community, to protect the dignity of individuals, and to respect human rights laws in force in Ontario.... ${ }^{45}$

The legal profession has historically not done a particular good job of diversifying itself. ${ }^{46}$ We are now seeing improvements; however, while the number of women and minority groups in law schools and the profession has increased, there is still a significant way to go in terms of diversity (and equality) at the highest levels of power and influence. ${ }^{47}$

In the end, what regulators largely care about, through codes of conduct focussed primarily on the protection of the public interest, are both integrity and competence. ${ }^{48}$ And with respect to the latter, the argument that I am advancing here puts pluralism and diversity very much at the

45 LSUC, Rules of Professional Conduct, supra note 38 at r. 1.03(1)(b). See further ibid. at r. 5.04(1) (Commentary), which provides that:

The [LSUC] ... acknowledges the diversity of the community of Ontario in which lawyers serve and expects them to respect the dignity and worth of all persons and to treat all persons equally without discrimination.... This rule sets out the special role of the profession to recognize and protect the dignity of individuals and the diversity of the community in Ontario.

\footnotetext{
${ }^{46}$ See e.g. Constance Backhouse, “Gender and Race in the Construction of 'Legal Professionalism': Historical Perspectives”, paper presented at Chief Justice of Ontario's Advisory Committee on Professionalism, First Colloquium on the Legal Profession (October 2003), online: LSUC

$<\mathrm{http}: / /$ www.lsuc.on.ca/media/constance_backhouse_gender_and_race.pdf $>$.
}

${ }^{47}$ See e.g. Michael Ornstein, Racialization and Gender of Lawyers in Ontario, a Report for the LSUC (Toronto: LSUC, April 2010), online: LSUC < http://www.lsuc.on.ca/media/convapril10_ornstein.pdf >. See further Fiona M. Kay, "Integrity in a Changing Profession: Issues of Diversity and Inclusion" (28 November 2005), online: LSUC $<$ http://www.lsuc.on.ca/media/kaydiversityintegrity.pdf $>$; Rosemary Cairns Way, "Reconceptualizing Professional Responsibility: Incorporating Equality" (2002) 25 Dal. L.J. 27; David B. Wilkins, "Identities and Roles: Race, Recognition, and Professional Responsibility” (1998) Md. L. Rev. 1502.

${ }^{48}$ See e.g. LSM, Code of Professional Conduct, supra note 37 at "Preface"; CBA, Code of Professional Conduct, supra note 39 at "Preface". 
centre of what it means for a lawyer to be competent. Put differently, if lawyers - individually and collectively - are not "responsive" 49 to the changing needs of their increasingly diverse clients, then they are simply not fully competent to practice law in a sophisticated and multicultural global economy like the one we enjoy here in Canada. ${ }^{50}$ As a starting point, that professional attentiveness must include a meaningful understanding of individual client needs. Involved here are foundational lawyering skills including how to communicate with clients, take instructions, develop legal arguments and strategies, etc. In addition, the professional attentiveness that I am talking about here must also include an understanding of the diverse norms and rules that guide various client needs and related social relationships. On this latter point, when it comes to understanding the law, lawyers (and judges) have increasingly been looking to international ${ }^{51}$ and comparative ${ }^{52}$ legal materials, in addition to typical domestic legal sources, for guidance on how to understand local legal rights and obligations. How we understand and interpret our legal texts benefits greatly from studying how others look at similar,

\footnotetext{
${ }^{49}$ See FLSC, Model Code of Professional Conduct, supra note 40 and accompanying text.

${ }^{50}$ For various discussions of competence and culture in the context of the legal profession, see e.g. Sue Bryant and Jean Koh Peters, "Five Habits for Cross-Cultural Lawyering", in Race and Justice, c. 4, online: Maine Law School $<$ http://mainelaw.maine.edu/news/conferences/justice/SueBryantsagefivehabits.pdf $>$; Jamie Y. Whitaker, "Remedying Ethical Conflicts in a Global Legal Market" (2006) 19 Geo. J. Legal Ethics 1079; James Heffernan, "An American in Beijing: An Attorney's Ethical Considerations Abroad with a Client Doing Business with a Repressive Government” (2006) 19 Geo. J. Legal Ethics 721; Halina Ward, "The Interface Between Globalization, Corporate Responsibility, and the Legal Profession” (2004) 1 U. St. Thomas L.J. 813.

${ }^{51}$ For judicial statements on the importance of international law, values and principles in the context of understanding and interpreting Canadian law, see e.g. Baker v. Canada (Minister of Citizenship and Immigration), supra note 32 at para. 70; Canada (Prime Minister) v. Khadr, [2010] 1 S.C.R. 44 at para. 23; Suresh v. Canada (Minister of Citizenship and Immigration), [2002] 1 S.C.R. 3 at para. 60. For a useful discussion, see Karen Knop, "Here and There: International Law in Domestic Courts", (2000) 32 NYU J. Int'l L. \& Pol. 501.

${ }^{52}$ For judicial statements on the importance of comparative law, see e.g. Théberge v. Galerie d'Art du Petit Champlain inc., [2002] 2 S.C.R. 336 at para. 6; Harvard College v. Canada (Commissioner of Patents), [2002] 4 S.C.R. 45 at paras. 12-14. See further Hon. Gérard V. La Forest, "The Expanding Role of the Supreme Court of Canada in International Law Issues" (1996) 34 Can. Y.B. Int'l L. 89 at 100-101. For concerns regarding the use of comparative law, see e.g. Bijon Roy, "An Empirical Study of Foreign Jurisprudence and International Instruments in Charter Litigation" (2004) 62 U.T. Fac. L. Rev. 99 at paras. 32-42 (QL).
} 
as well as different, legal issues and instruments (which is part of an ongoing globalization of socio-legal materials). Equally important is an understanding of the multiplicity of norms, practices, customs and expectations that guide our complex social arrangements, which have not historically been understood as "law", but which - together - Jessup rightly characterized as "law" (broadly defined). ${ }^{53}$ In the end, a broad understanding of the sources, elements and guiding norms of the diversity of Canada must amount to at least part of what it means to be a competent, ethical lawyer.

Finally, still in the context of understanding pluralism as an element of professionalism, it is clearly important to start the conversation not with regulation through the rules of professional conduct, but rather with education through creative legal education reform. While pluralism should be a topic of general educational importance, law schools - and continuing legal educators for that matter ${ }^{54}$ - need to do their part in terms of instilling a sense of globalism and the relevance of pluralism as core elements of professional education. Most Canadian law schools are now expanding their international offerings ${ }^{55}$ and all of them are expanding their professional course offerings. ${ }^{56}$ And some, although certainly not all, professional conduct

\footnotetext{
${ }^{53}$ See supra note 20 and accompanying text.

${ }^{54}$ For a discussion of the importance of continuing legal education in professionalism, see Stephen G.A. Pitel and Trevor C.W. Farrow, "Symposium Special Feature: Lifelong Learning in Professionalism - An Introduction" (2010) Can. Legal Ed. Annual Rev. 3.

${ }^{55}$ See e.g. Osgoode Hall Law School, Office of the Dean, Annual Report - Academic Year 2006-2007, supra note 3 at pp. 2, 7. For an international example, see Harvard Law School, Office of Career Services, "The New 1L Curriculum", online: HLS <http://www.law.harvard.edu/current/careers/ocs/employers/about-our-students/the-new11-curriculum.html>.

${ }^{56}$ Increasing student exposure to professionalism is consistent with the current literature on best practices in adult legal education. See e.g. William M. Sullivan et al., Educating Lawyers: Preparation for the Profession of Law (San Francisco: Jossey-Bass, 2007) at c. 4; Roy Stuckey and Others, Best Practices for Legal Education: A Vision and a Road Map (United States: Clinical Legal Education Association, 2007) at c. 3, pt. D; Michele Leering et al., "Developing a Disciplined Approach to Reflection: Encouraging Reflective Practice, Integrated Learning, and Sharing Promising Practices - Part I" (2011), online: Global Alliance for Justice Education $<$ http://www.gaje.org/abstract-michele/>. Further, teaching professionalism is also now mandated by provincial regulatory policies, which have generally adopted the FLSC's approach to standardizing legal education in Canada
} 
courses look at issues of diversity and globalization, often through a lens of cultural competence. $^{57}$ However, self-consciously combining globalism and professionalism - with a view to defining legal professionalism fundamentally through the lens of pluralism - has not been the practice of most law faculties. The argument in this lecture is that it should be. That is certainly what we have done at Osgoode Hall Law School, for example, in a mandatory first year course called "Ethical Lawyering in a Global Community". 58 The learning objectives for that course are attached as Appendix A to this lecture. I am of course biased in my view that this course is a progressive and important element of our faculty's core curricular offerings. And while not all students appreciate the course, our experience is that many - if not most - do. Further, in terms of external reports, the course has been considered to be an example of "best practices" among the "top" Canadian law schools. ${ }^{59}$ There are certainly many ways to approach the issue pedagogically, and Osgoode's is but one. However, whether through a stand-alone course, a series of different course offerings or through discussions pervasively placed throughout the curriculum (or ideally as a combination of all three), legal educators need to do something significant in terms of making pluralism and professionalism part of their core curricular offerings.

to at least a basic level of core competencies. See e.g. FLSC, Task Force on the Canadian Common Law Degree, Final Report (October 2009), online: <http://www.flsc.ca/_documents/Common-Law-Degree-Report-C(1).pdf>; FLSC, Common Law Degree Implementation Committee, Final Report (August 2011), online:

$<$ http://www.flsc.ca/_documents/Implementation-Report-ECC-Aug-2011-R.pdf>. See further FLSC, National Admission Standards Project (September 2012), online:

$<$ http://www.flsc.ca/_documents/NASCompetenciesSept2012.pdf>.

${ }^{57}$ For recent Canadian teaching materials that look at cultural competence as a matter of professional responsibility, see Alice Woolley et al., eds., Lawyers' Ethics and Professional Regulation, 2d ed. (Markham: LexisNexis, 2012) at 145-146, 165-186, 601-617. Compare however Beverly G. Smith, Professional Conduct for Lawyers and Judges, 4th ed. (Fredericton: Maritime Law Book, 2011), which does not take up the issue in a meaningful way.

${ }^{58}$ See supra note 3 and accompanying text.

${ }^{59}$ See Monika Warzecha, Special Report, "Knight Schools: Fifth annual guide to schools for students who want to change the world" Corporate Knights (Best 50 Issue 2008) 31 at 35. 


\section{Pragmatism}

Finally, in addition to the descriptive realities of pluralism and the normative requirements of professionalism, it is also important to look at the pragmatic aspects of this inquiry. In a nutshell, being open to pluralism - particularly through an understanding of and dedication to diversity - is good for business. Clients are increasingly demanding that their legal counsel not only understand pluralism and diversity, they want their legal counsel to be diverse. In Canada, a good example to look at is the work of A Call to Action Canada. Its mission statement, which has been signed by a number of major Canadian institutions, ${ }^{60}$ provides that:

As Corporate Legal Officers, we affirm our commitment to diversity in the legal profession. Our action is based on the need to enhance opportunity in the legal profession for women and minorities and our recognition that the legal and business interests of our clients require legal representation that reflects the diversity of our employees, customers and the communities where we do business. In furtherance of this commitment, this is intended to be a Call to Action for the profession generally, in particular for our law departments and for the law firms with which our companies do business.

In an effort to realize a truly diverse profession and to promote diversity in law firms, we commit to taking action consistent with the Call to Action. To that end, we pledge that we will make decisions regarding which law firms represent our companies based in significant part on the diversity performance of the firms.

We intend to look for enhanced opportunities for those firms which positively distinguish themselves in this area. We intend to look for opportunities to direct work to firms which are controlled by, or have a substantial number of, partners who are women or minorities. We further intend to end or limit our relationships with firms whose performance consistently evidences a lack of meaningful interest in being diverse. ${ }^{61}$

As contemplated by this mission statement, promoting diversity and being diverse is a good thing from a fundamental human rights perspective, as well as for reflecting and serving the

\footnotetext{
${ }^{60}$ Signatories include Accenture Inc., Deloitte and Touche LLP, E.J. Du Pont Canada Company and Royal Bank of Canada. See A Call to Action Canada, "Signatories to the Mission Statement", online:

$<$ http://acalltoactioncanada.com/mission-statement $>$. See further Jennifer Chow, "The Call to Diversify the Legal Profession" (2011) 44 U.B.C. L. Rev. 25 at 10-21.

${ }^{61}$ A Call to Action Canada, "Mission Statement”, ibid. See also further supra note 29 and accompanying text.
} 
communities in which we live and work, ${ }^{62}$ and for respecting and promoting professionalism aspirations and obligations with respect to pluralism. ${ }^{63}$ Further, however, doing so is also good for business. There is a growing body of evidence to suggest that diversity on boards and in the workforce has a positive impact on performance. ${ }^{64}$ In the context of gender diversity, one relatively recent study indicated that companies with more woman board members outperformed those with fewer women board members in terms of return on equity, return on sales and return on invested capital. ${ }^{65}$ A different study found that the stock performance of selected companies headed by women outperformed that of the overall market, which is primarily made up of companies dominated by men. ${ }^{66}$ And other reports and studies support these findings. ${ }^{67}$

\footnotetext{
${ }^{62}$ See generally supra pt. 1.

${ }^{63}$ See generally supra pt. 2. In particular, see e.g. LSUC, Rules of Professional Conduct, supra note 38 at $\mathrm{r}$. 1.03(1)(b) and r. 5.04(1) (Commentary).

${ }^{64}$ See e.g. Institute of Corporate Directors, Diversity in the Boardroom: Findings and Recommendations of the Institute of Corporate Directors (5 December 2011), online:

$<$ http://www.icd.ca/Content/Files/News/2011/201112_BoardDiversity_ENG_FINAL.pdf $>$; Catalyst, Why Diversity Matters: Research studies 2005-2010 (Catalyst Information Centre, 2 November 2010), online:

$<$ http://www.pwi.be/Resources/Documents/Catalyst-Why_Diversity_Matters_11-2-10.pdf $>$; Retention of Women in Law Task Force, The Business Case for Retaining and Advancing Women Lawyers in Private Practice (Vancouver: Law Society of British Columbia, July 2009), online:

$<$ http://www.lawsociety.bc.ca/docs/publications/reports/Retaining-women-business-case.pdf $>$. See further Beth Bilson, "Dividend of Diversity: The Impact of Diversity on Organizational Decision Making" (2011) 44 U.B.C. L. Rev. 9 (QL); Judy Rosener, "Women on Corporate Boards Makes Good Business Sense", Womens Media (2 April 2009), online: $<$ http://www.womensmedia.com/lead/87-women-on-corporate-boards-makes-good-businesssense.html>.

${ }^{65}$ Lois Joy et al., The Bottom Line: Corporate Performance and Women's Representation on Boards (Catalyst, 2007), cited in Why Diversity Matters: Research studies 2005-2010, ibid. at 3.

${ }^{66}$ Michael K. Ozanian, "Girls Rule", Forbes (25 October 2010), cited in Why Diversity Matters: Research studies 2005-2010, ibid. at 5.

${ }^{67}$ See e.g. McKinsey \& Company, Women Matter: A Corporate Performance Driver (McKinsey, 2007); Michel Ferrary, "Soapbox: why women managers shine", The Financial Times (2 March 2009); Michel Ferrary, CAC 40: les entreprises feminisees resistent-elles mieux a la crise boursiere? (Ceram Business School, 2009), all cited in Why Diversity Matters: Research studies 2005-2010, ibid. at 5. See also Diversity in the Boardroom: Findings and Recommendations of the Institute of Corporate Directors, supra note 64 at 6.
} 
In addition to enhanced financial performance, studies have found that diversity on boards and in the workforce can have positive impacts on a number of relevant performance indicators. For example, various studies - primarily relating to gender diversity but also with respect to other forms of diversity including race, etc. - indicate that diversity can:

- increase innovation; $^{68}$

- promote creative thinking and the avoidance of "groupthink"; 69

- improve productivity and problem-solving abilities; $;^{70}$

- promote overall corporate governance; ${ }^{71}$

- increase employee satisfaction and engagement; ${ }^{72}$

- promote the representation of, and engagement with, current and future local and international clients - many of whom are demanding increased diversity; ${ }^{73}$

- help to avoid potential discrimination and harassment lawsuits, lower company morale, and loss of reputation; ${ }^{74}$ and

- have a positive impact on the recruitment and retention of workers. ${ }^{75}$

${ }^{68}$ Why Diversity Matters: Research studies 2005-2010, ibid. at 7.

${ }^{69}$ Why Diversity Matters: Research studies 2005-2010, ibid. at 8; Diversity in the Boardroom: Findings and Recommendations of the Institute of Corporate Directors, supra note 64 at 5; Bilson, "Dividend of Diversity: The Impact of Diversity on Organizational Decision Making", supra note 64 at para. 16.

${ }^{70}$ Why Diversity Matters: Research studies 2005-2010, ibid. at 9.

${ }^{71}$ Diversity in the Boardroom: Findings and Recommendations of the Institute of Corporate Directors, supra note 64.

${ }^{72}$ Why Diversity Matters: Research studies 2005-2010, supra note 64 at 9.

${ }^{73}$ Why Diversity Matters: Research studies 2005-2010, ibid. at 11-12; Diversity in the Boardroom: Findings and Recommendations of the Institute of Corporate Directors, supra note 64 at 6; Bilson, "Dividend of Diversity: The Impact of Diversity on Organizational Decision Making", supra note 64 at para. 5; Molly McDonough, "Demanding Diversity: Corporate Pressure is Changing Racial Mix at Some Law Firms", ABA Journal (28 March 2005), online: ABA $<$ http://www.abajournal.com/magazine/article/demanding_diversity/>.

${ }^{74}$ Why Diversity Matters: Research studies 2005-2010, ibid. at 13. 
What all of this indicates, from a pragmatic - "business case" - perspective, is that issues of pluralism and diversity are of major significance to the clients that lawyers serve. As such, these issues need to be seen as major elements of the professional interests and obligations of competent counsel.

\section{CONCLUSION}

I started this lecture with a very brief look at the pluralism elements of Isaac Pitblado's life. The importance of doing so, I hope, has become clear. Pluralism - and in particular an attentiveness to the diverse characteristics and needs of the increasingly global communities that lawyers serve, together with the multiplicity of norms that guide those communities - has not adequately formed part of what counts as being a professional. In Ontario, for example, the Chief Justice of Ontario's Advisory Committee on Professionalism developed a useful list of ten "elements of professionalism" ${ }^{76}$ They include: scholarship, integrity, honour, leadership, independence, pride, spirit and enthusiasm, civility and collegiality, service to the public good, and balanced commercialism. ${ }^{77}$ These are all important characteristics of professionalism. However, not one of them focuses on equality, diversity or pluralism. In fact, none of those three words is mentioned at all.

\footnotetext{
75 Why Diversity Matters: Research studies 2005-2010, ibid. at 14; Diversity in the Boardroom: Findings and Recommendations of the Institute of Corporate Directors, supra note 64 at 6; David B. Wilkins, "Why Global Law Firms Should Care About Diversity: Five Lessons from the American Experience" (2000) 2 Eur. L.J. Reform 415 at 421.

${ }^{76}$ Chief Justice of Ontario, Advisory Committee on Professionalism, Working Group on the Definition of Professionalism, "Elements of Professionalism" (October 2001, rev. December 2001 and June 2002), online: LSUC $<$ http://www.lsuc.on.ca/media/definingprofessoct2001 revjune2002.pdf $>$.

${ }^{77}$ See ibid.
} 
I have argued in this lecture that this blind spot in our collective thinking is clearly a problem. As both our former and current Governor General of Canada have so clearly stated, ${ }^{78}$ our approach to professionalism, and what it means to be an ethical lawyer in a global community, must change so that we "stay relevant ... and continuously strive for the good.",79 Doing otherwise will cheapen what it is to be a lawyer, it will limit our ability competently to represent our clients, and it will impoverish the potential of our increasingly multicultural communities.

\footnotetext{
${ }^{78}$ See supra notes $1-2$.

${ }^{79}$ See supra note 2.
} 


\section{APPENDIX A}

\section{OSGOOde HaLl LAW SCHOOL}

\section{ETHiCAL LAWYERING in a GLOBAL COMMUNity 2012-2013}

\section{COURSE LEARNING OBJECTIVES}

The overall objective of this course is to encourage students to engage in an expansive, moral conversation about lawyering that will lead to a reflective and critical approach to ethical lawyering in a global community. As lawyers, who we are, for whom, how and where we act, and on what basis are central questions for this course.

By the end of the course, students should be able to:

- demonstrate a basic understanding of the history, structure and regulatory processes of the Canadian legal profession;

- demonstrate knowledge of the norms traditionally associated with the legal profession as reflected in rules of professional conduct and related enabling legislation;

- appreciate the legal profession as, itself, a normative system, wherein the norms are not given and static but contested and shifting;

- appreciate the breadth and diversity of visions or philosophies of lawyering;

- discern some ethical frameworks that are appropriate to various lawyering roles and practice contexts;

- demonstrate the ability to think critically about the legal profession, professionalism and the administration of justice;

- demonstrate an understanding of some of the basic professional obligations and practice issues relating to the lawyering role, including the fiduciary nature of the lawyer-client relationship, communication and civility, competence, confidentiality and disclosure, conflicts of interest, equality and diversity, etc.;

- demonstrate an understanding of multiple conceptions of access to justice and the public interest, two of the central norms claimed by the legal profession;

- demonstrate knowledge of the multiplicity of legal and normative orders in which lawyering occurs and understand how this multiplicity of orders may impact both client representation and the collective responsibilities of the profession;

- engage in ethical deliberations about legal problems in manners that are open to multiple viewpoints, moral perspectives and legal and social orders;

- appreciate some of the many and varied impacts of globalization on the practice of law and the regulation of the legal profession;

- demonstrate an understanding of some basic international, comparative and transnational concepts that relate to the lawyering process;

- identify and apply connections between the knowledge, skills and contextual discussions raised in this course and other law and pre-law school courses and experiences as well as in the Osgoode Public Interest Requirement (OPIR) program; and

- work collaboratively with others to resolve concrete professional problems. 